\author{
어육 수리미를 첨가한 가우다 치즈의 품질특성 \\ 김경희 ${ }^{1} \cdot$ 최희영 ${ }^{1} \cdot$ 전순실 $^{2} \cdot$ 배인휴 $^{3 *}$ \\ ${ }^{1}$ (재)임실치즈과학연구소, ${ }^{2}$ 순천대학교 식품영양학과, ${ }^{3}$ 순천대학교 동물자원과학과
}

\title{
Quality Properties of Gouda Cheese Added with Fish Surimi
}

\author{
Kyounghee $\mathrm{Kim}^{1}$, Heeyoung $\mathrm{Choi}^{1}$, Soonsil Chun ${ }^{2}$ and Inhyu $\mathrm{Bae}^{3 *}$ \\ ${ }^{1}$ Imsil Institute of Cheese Science, Iimsil-Gun 566-700, Korea, ${ }^{2}$ Department of Food and Nutrition, Sunchon National University, \\ Suncheon 540-742, Korea, ${ }^{3}$ Department of Animal Science and Technology, Sunchon National University, Suncheon 540-742, Korea
}

\begin{abstract}
The effects of adding fish surimi to Gouda cheeses on quality characteristics during ripening were investigated. Cheese samples were prepared with $1.0 \%$ fish surimi, changes in chemical composition, lactic acid bacterial population, $\mathrm{pH}$, non casein nitrogen, non protein nitrogen, water-soluble nitrogen, were monitored every 3 weeks during ripening. The electrophoresis patterns of cheese protein and the consumer's sensory evaluation test of Gouda cheese added with fish surimi also were analyzed. Slightly higher amounts of moisture, crude ash, crude protein, and crude fat were observed in the cheese supplemented with the fish surimi compared to the control cheese. The results suggested that the Gouda cheese prepared with fish surimi did not affect appearances or consumer's sensory characteristics of the cheeses.
\end{abstract}

(Key words : Gouda cheese, Fish surimi, Cheese ripening, Consumer's sensory evaluation)

\section{서 론}

수리미의 품질과 등급은 수분함량, 백색도, 불순물의 함량, 겔 강 도 등에 의해 결정되므로 수리미 가공원료로는 주로 백색 육 어류 가 사용 된다(Lanier, 1986; Park and Morrissey, 2000). 최근 어육 수리미 제품은 비린내를 느낄 수 없으면서 잔가시에 대한 부 담이 없어 서구뿐만 아니라 우리나라에서도 소비가 증가되고 있는 대표적인 수산가공품 중의 하나이다(Park and Morrissey, 2000). 어육 수리미에 관한 연구로는 산과 알칼리 공정으로 제조한 어육 수리미의 가열 겔에 미치는 근 형질단백질과 $\mathrm{NaCl}$ 의 영향(Choi, 1999), 산과 알칼리 $\mathrm{pH}$ 에서 어육 단백질의 용해를 이용한 수리미 제조(Park, 2003), 원료 육의 혼합비율에 따른 게 맛 어육소시지 의 조직학적 및 관능적 특성 (Jin et al. 2008) 등이 있으나 수리미 와 자연 치즈를 이용한 제반연구는 매우 미흡한 실정이다.

가우다 치즈(Gouda cheese)는 네덜란드가 원산지이고 에담 치 즈와 유사하며 정상적인 가우다 치즈는 에담 치즈 보다는 높은 지 방함량을 갖지만 건물함량 기준으로 보면 30 50\%까지 다양한 면 이 있다(Ellen, 2006). 외형은 원형이나 벽돌 형태이고 치즈 무게 는 $600 \mathrm{~g}$ 에서 $20 \mathrm{~kg}$ 까지 다양한 중량을 가진다 (Hill, 2007).

본 연구에서는 가우다 치즈가 맛이 온화하고 독특한 풍미를 가지 며, 어육 수리미와 같은 백색이기 때문에 가열 젤의 백색 도를 크
게 감소시키지 않고, 제품에 적절한 풍미를 부여할 뿐 아니라 최근 한국의 신세대가 해산물 소비를 기피하면서도 자연 치즈에 대한 기 호도가 점차 상승하고 있다는 점에 착안하여 신세대의 기호에 적합 한 신규 치즈 제품 개발이 가능할 것으로 판단되었다. 본 연구에서 는 각종 문헌 수집과 예비시험을 통해 세계 주요 치즈 중 한국인에 게 잘 알려진 가우다 치즈(Gouda cheese)를 선발하고 기본 시험 을 실시한 후, 어육 수리미를 첨가한 치즈를 제조하여 어육 수리미 첨가가 가우다 치즈 품질에 미치는 영향을 조사하였다.

\section{재료 및 방법}

\section{1. 원유}

전남 순천시 서면 지본리 518 번지 소재, 순천대학교 부속동물사 육장에서 사육중인 홀스타인-프리지안(Holstein-Friesian)종의 원 유를 당일 착유하여 사용하였다 ( $\mathrm{pH}: 6.8$, TA: 0.14- 0.15\%).

\section{2. 치즈 starter}

치즈 Starter는 Danisco사의 Provat 505 (Lactococcus lactis subsp. lactis, Lactococcus lactis subsp. cremoris, Lactococcus

* Corresponding author: Inhyu Bae, Department of Animal Science \& Technology, Sunchon National University, 255 Jungangro, Suncheon, 540-742, Korea. Tel: 82-61-750-3233, Fax: 82-61-750-3233, E-mail: ihbae@scnu.ac.kr 
lactis subsp. lactis biovar. diacetylactis, Lenconostoc mesenteroides subsp. cremoris, Danisco Co., Denmark)를 10\% $(\mathrm{w} / \mathrm{v})$ 멸균 환원탈지유(Seoul Milk Cooperation, Korea, Ansan) 에 2회 증균 배양하여 활력을 증진시켜 사용하였다.

\section{3. 어육 수리미}

본 실험에 사용한 어육 수리미는 한성식품 (Hansung Food Co. Korea)이 미국수산회사(America Seafood Co. Ltd.)로 부터 수입 한 1 등급 중 최 우수급 $(\mathrm{FA})$ 의 수리미제품을 사용하였다. Jin 등 (2007)이 보고한 어육 수리미의 개략적인 조성분 함량은 수분 $80.30 \%$, 조단백질 $17.50 \%$, 조지방 $0.70 \%$, 그리고 조회분 $1.50 \%$ 로 구성된 것으로 나타나 어육 수리미가 수분함량과 조단백질의 함 량이 높지만 본 연구에서는 어육 수리미 첨가량이 전체 치즈 량의 $1.0 \%$ 에 불과함으로 치즈 숙성에 따른 일반성분의 변화에 큰 영향 을 미치지 않을 것으로 사료되었다.

\section{4. 어육 수리미 첨가 가우다 치즈의 제조}

치즈 제조는 Hill (2007)의 방법에 따라 제조하였다. 먼저, 어육 수리미 적정 첨가량을 검토하고자 기본 시험치즈를 다음과 같이 제 조하였다. 즉, 어육 수리미를 원유의 $1.0 \%, 2.0 \%, 3.0 \%$ 량으로 준 비하여 각각 다른 치즈 벳트에 체로 걸러 치즈원유에 첨가하여 저 온살균 후 치즈를 제조하고 1 개월간 숙성 후에 관능평가를 실시하 였다. 기본 시험치즈 제조 후 관능검사와 조직도 검사 결과 어육 수리미의 고유 비린내가 나지 않으며 치즈의 조직감 보전성이 좋은 것으로 나타난 첨가량인 $1.0 \%$ 구를 적정 첨가구로 최종 선정하여 공시치즈를 제조하였다. 즉, 신선한 원유의 $1.0 \%$ 를 체에 걸려 원유 에 첨가하여 살균 $\left(63^{\circ} \mathrm{C}, 30\right.$ 분 $)$, 냉각 $\left(32^{\circ} \mathrm{C}\right)$ 하고 치즈 뱃트에 정치 하고 스타터를 접종 $(1.0 \%), 30$ 분에 걸쳐 배양하였다. 원유의 적정 산도 도달을 확인한 후 응유효소(Rennet)를 첨가하였다. Rennet은 Chr. Hansen사의 DOUBLE STRENGTH 290 Halal Calf Rennet (Christian Hansen Co., Denmark)으로 원유의 0.019\% $(19 \mathrm{~mL} / 100 \mathrm{Kg})$ 를 증류수에 20 배 희석, 첨가하여 응고시켰다. 응 고된 커드는 $8.0 \sim 10 \mathrm{~mm}$ 크기로 절단한 뒤 15 분간 천천히 교반한 후 커드 높이까지 유청을 제거하고, $70 \sim 80^{\circ} \mathrm{C}$ 의 온수를 사용하여 2 분에 $1.0^{\circ} \mathrm{C}$ 씩 올리는 속도로 $38^{\circ} \mathrm{C}$ 까지 가온, 교반 한 후 유청을 커 드 표면이 보일 때까지 제거한 다음 유청 내에서 커드의 2 배 무게 로 40 분간 예비 압착하여 유청을 배제하고, 성형, 가압하여 수리미 가우다 치즈를 제조한 후 $14^{\circ} \mathrm{C}, 90 \sim 95 \%(\mathrm{R} / \mathrm{H})$ 의 숙성 조건하에서 4개월간 숙성하였다.

\section{5. 치즈의 생균수 측정}

치즈의 숙성 중 유산균 생균수는 3주마다 실험하였다. 즉, 시료 는 멸균 식염수(saline)와 분취한 치즈를 2:1의 비율로 혼합한 뒤
homogenizer(M. Zipper GmbH, Etzenbach, Germany)로 $20,000 \mathrm{rpm}$ 에서 2 분간 3 회에 걸쳐 균질하였다. 치즈 내 유산균의 생균수는 Richardson(1983)의 방법에 따라 10진 희석 후 평판 (Petri dish)에 $1.0 \mathrm{~mL}$ 분주하고, $\mathrm{MRS}$ (BD Bionutrients, USA) 배지를 이용하여 standard plate count법으로 $37^{\circ} \mathrm{C}$ 에서 48 시간 배 양 후 집락의 수가 30 300개 범위로 나타난 평판을 선별, 계수하 여 CFU (colony forming unit) $/ \mathrm{mL}$ 로 표시하였다.

\section{6. 치즈의 $\mathrm{pH}$ 측정}

치즈 숙성 중 $\mathrm{pH}$ 는 생균수 측정법과 동일한 방법으로 생리식염 수 (saline)와 치즈를 2:1의 비율 (saline: cheese $=20 \mathrm{~mL}: 10 \mathrm{~g}$ )로 균질기 (M. Zipperer GmbH, Etzenbach, Germany)에서 20,000 $\mathrm{rpm}$ 으로 2분간 균질화한 다음 $\mathrm{pH}$ meter(Istek Model 720p, Korea)로 3 주 간격으로 15 주 동안 그 변화를 측정하였다.

7. 치즈의 숙성 중 $\mathrm{NPN}$ (non protein nitrogen), $\mathrm{NCN}$ (non casein nitrogen), WSN (water soluble nitrogen) 의 변화

치즈 숙성 중 총 단백질의 분해수준을 측정하기 위하여 Bütikofer (1993)의 방법으로 NPN (non protein nitrogen), NCN (non casein nitrogen), WSN(water soluble nitrogen)의 변화를 측정하였다. 먼저 이들의 변화를 측정하기 위한 시료의 처리는 멸 균 식염수와 치즈를 2:1의 비율(식염수 $40 \mathrm{~mL}$ 에 치즈 $20 \mathrm{~g}$ )로 homogenizer (M. Zipper GmbH, Etzenbach, Germany)로 균질 처리한 후 $5^{\circ} \mathrm{C}, 3,000 \times \mathrm{g}$ 에서 30 분간 원심분리 (Supra $25 \mathrm{~K}$, Hanil Science Industrial, Korea)하여 상층부의 지방을 걷어내고 남은 액을 여과(Whatman No. 2)하여 Hull (1947)의 방법에 따라 $\mathrm{NPN}$ 과 $\mathrm{NCN}, \mathrm{WSN}$ 함량을 측정하였다.

우선 NPN 측정을 위하여 여과액 $2.5 \mathrm{~mL}$ 에 Reagent $\mathrm{A}(12 \%$ trichloroacetic acid) $5.0 \mathrm{~mL}$ 와 증류수 $0.5 \mathrm{~mL}$ 를 혼합하여 실온에 서 20 분간 방치한 뒤, 여과 (Whatman No 42)하여 $2.5 \mathrm{~mL}$ 를 취하 였다. 이후 여과 액 $2.5 \mathrm{~mL}$ 에 Reagent $\mathrm{B}$ (증류수 $500 \mathrm{~mL}$ 에 sodium carbonate $75 \mathrm{~g}$ 와 sodium hexametaphosphate $10 \mathrm{~g}$ 를 녹 인 것) 용액 $5.0 \mathrm{~mL}$ 와 Reagent $\mathrm{C}$ (phenol reagent $50 \mathrm{~mL}$ 와 증류 수 $100 \mathrm{~mL}$ 를 혼합한 것) 용액 $1.5 \mathrm{~mL}$ 를 순서대로 혼합하여 $30^{\circ} \mathrm{C}$ 항온수조에서 30 분간 발색하였다.

$\mathrm{NCN}$ 의 측정은 위의 여과 액 $2.5 \mathrm{~mL}$ 에 $1 \mathrm{M}$ acetate buffer $(\mathrm{pH}$ 4.6) $2.5 \mathrm{~mL}$ 를 가하여 $37^{\circ} \mathrm{C}$ 항온수조에서 20 분간 방치한 뒤, Whatman No. 42 여과지로 여과한 여과액을 NPN과 같은 방법으 로 발색시켰다.

$\mathrm{WSN}$ 의 변화는 치즈 $5.0 \mathrm{~g}$ 에 증류수 $20 \mathrm{~mL}$ 를 넣고 분쇄 및 균 질화한 후 Whatman No. 2 여과지로 여과하여 NPN과 같은 방법 으로 발색시켰다. 발색이 끝난 후 UV-spectrophotometer (Smart Plus Spectrophotometer Co., Korea)를 사용하여 NPN은 650 
$\mathrm{nm}, \mathrm{NCN}$ 은 $570 \mathrm{~nm}, \mathrm{WSN}$ 은 $570 \mathrm{~nm}$ 에서 각각의 흡광도를 측정 하였으며, 이들의 함량은 tyrosine을 표준물질로 하여 얻은 회귀직 선 식으로 계산하였다.

\section{SDS-polyacrylamide gel electrophoresis (SDS-PAGE)}

숙성 중 치즈의 단백질 분해 도는 LaemmLi (1970)와 Creamer (1982)의 방법으로 실시하였다. 치즈 시료 액은 치즈시료 $0.3 \mathrm{~g}$ 에 $12.0 \% \mathrm{TCA} \quad 6.0 \mathrm{~mL}$ 를 가하여 침전시키고 Whatman No. 42로 여과하였으며, 침전물은 $0.076 \mathrm{M}$ Tris-citrate buffer $(\mathrm{pH} 9.0)$ 에 약 $30 \mathrm{mg} / \mathrm{mL}$ 농도로 용해시켰다. 위 용해액을 전기영동 electrode buffer에 48 시간 투석 $\left(4^{\circ} \mathrm{C}\right)$ 시키고 이것을 $40 \mu \ell$ 를 취하여 $\mathrm{SDS}$ sample buffer $10 \mu l$ 와 섞어 3 분간 끓여 단백질을 변성시킨 후 전 기영동 시료로 사용하였다. 하부 전극 조에는 $25 \mathrm{~mL}$ 의 separating gel을 채우고 30 60분간 두어 gel을 굳게 만들었다. Stacking gel solution을 만들어 이미 굳은 separating gel 위에 붓고 comb를 꽂아 30 분 정도 두었으며, 형성이 완료된 gel을 전기영동 장치에 옮겼다. Gel을 Gel running tank에 장착한 후, upper tank와 lower tank에 tank buffer를 채웠다. Sample $10 \mu \ell$ 를 시료 구에 loading 한 후, $1.5 \mathrm{~mm}$ gel은 $30 \mathrm{~mA}$ 에 맞추고 sample이 바닥에 올 때까지 전기영동을 하였다. 전기영동 시 gel은 $\mathrm{pH} 8.8$ 의 $15 \%$ 농도로 사용하였으며 분자량 측정을 위한 표준단백질로서는 whole casein (Bio-Rad Laboratories, Hercules, CA, USA)을 marker 단백질로 사용하였다. 전기영동이 완료된 gel은 Coomassie brilliant blue Gel Stain으로 염색한 다음 탈색용액으로 탈색한 후 사진촬영 하였다.

\section{9. 일반성분}

치즈의 일반성분은 AOAC (1990)의 방법에 따라 수분은 oven 건조법, 조단백질 함량은 자동단백질분석기 (BÜCHI Labortechnik AG., Switzerland)를 이용하여 Kjeldahl법으로 분석하고, 조지방은 Roese Gottlieb법으로 측정하였다.

10. 소비자 기호도 검사

소비자 기호도 검사는 순천대학교 식품영양학과 학생 104명을 소비자로 하여 9점 척도 법을 이용하여 동일 설문지로 평가하였다. 이때 소비자 기호도의 평가 항목은 색(Color), 향(Flavor), 조직감 (Texture), 전반적인 기호도(Overall acceptability)로서 대단히 좋 아한다: 9점, 좋지도 싫지도 않다: 5점, 대단히 싫어한다: 1점으로 나타냈다. 시료의 준비 및 제시는 1 인분 portion size를 $15 \mathrm{~g}$ 로 정 하여 흰 플라스틱 접시에 담아서 제공하였다. 선별된 패널은 나 이·성별 등을 기록하였고 각 시료는 물 컵, 시료를 뱉는 컵과 정 수기에서 받은 물을 시료 사이에 제공하였다.

\section{1. 관능검사}

치즈 소비 경험이 있는 훈련된 패널로 구성된 요원 10 인에 의해 관능검사를 실시하였다. 평가는 Morris (1979) 및 Davis와 Law (1984)의 방법에 따라 각 항목 별로 9단계 평점 법(최고 9점, 최 저 1점)을 사용하여 시판 제품의 버터향(Aroma of Butter), 짠맛 (Salty), 쓴맛 (Bitterness), 수렴성 (Astringency), 부티르산 (Butyric acid) 등을 평가하였다. 항목은 대단히 강함 9점, 아주 강함 8점, 보통 강함 7점, 약간 강함 6점, 강하지도 약하지도 않음 5점, 약간 약함 4점, 보통 약함 3점, 아주 약함 2점, 대단히 약함 1점으로 검 사하였다.

\section{2. 통계처리}

표준 편차, 유의성 검정 및 표면 반응 분석은 통계프로그램인 JMP 7 (SAS 1999)을 사용하여 Box-Behnken법으로 실시하였으 며, 유의차는 $\mathrm{P}<0.05$ 수준에서 Fisher's Least Significant Difference test로 검증하였다.

\section{결과 및 고찰}

\section{1. 생균수의 변화}

어육 수리미를 첨가한 가우다 치즈의 생균수 변화는 Fig. 1에서 와 같이 숙성 기간이 경과함에 따라 감소경향을 나타냈는데 어육 수리미 첨가구가 대조 구 치즈보다 비교적 완만하게 감소하는 경향 을 보였다. 대조 구와 어육 수리미 첨가 구에서의 생균수의 변화는 유의적인 차이가 없었으며 $(\mathrm{P}<0.05)$ 어육 수리미의 첨가가 유산균 의 생존성에 큰 영향을 미치지 않았지만 가우다 치즈 제조에는 부 (負)의 영향보다는 정(正)의 영향을 미치고 있음을 알 수 있었다.

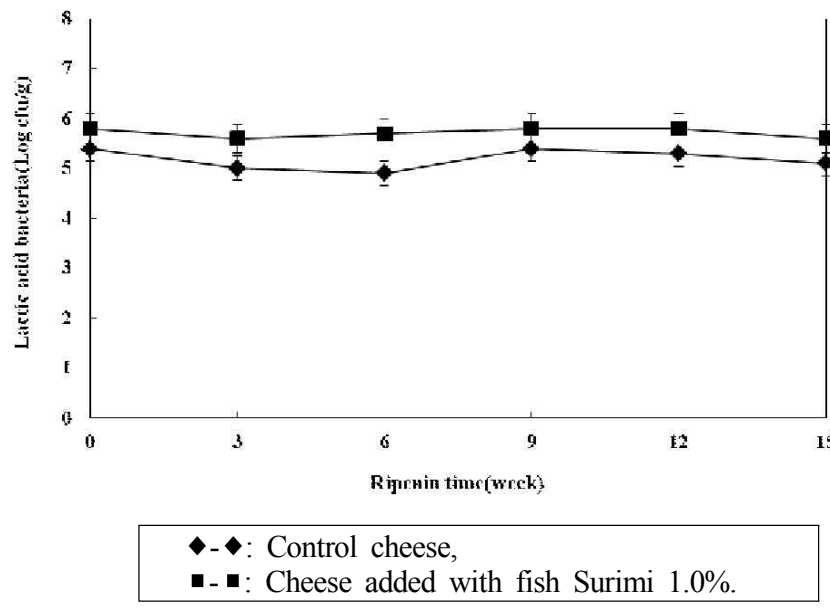

Fig. 1. Changes in lactic acid bacteria count during the ripening period of Gouda cheese added with fish Surimi. 
2. $\mathrm{pH}$ 변화

어육 수리미를 첨가한 가우다 치즈의 숙성 중 $\mathrm{pH}$ 를 측정한 결과 는 Fig. 2에서 보는 바와 같다. 어육 수리미 단백질은 등전점 $\mathrm{pH}$ 5.0 부근에서 침전시켜 침전단백질을 회수하는 방법으로 제조되므 로 Choi 등 (2002)의 보고에서와 같이 첨가구와 대조구는 $\mathrm{pH} 5.0$ 부근에서 유의적인 차이가 없는 것 $(\mathrm{P}<0.05)$ 으로 나타났다.

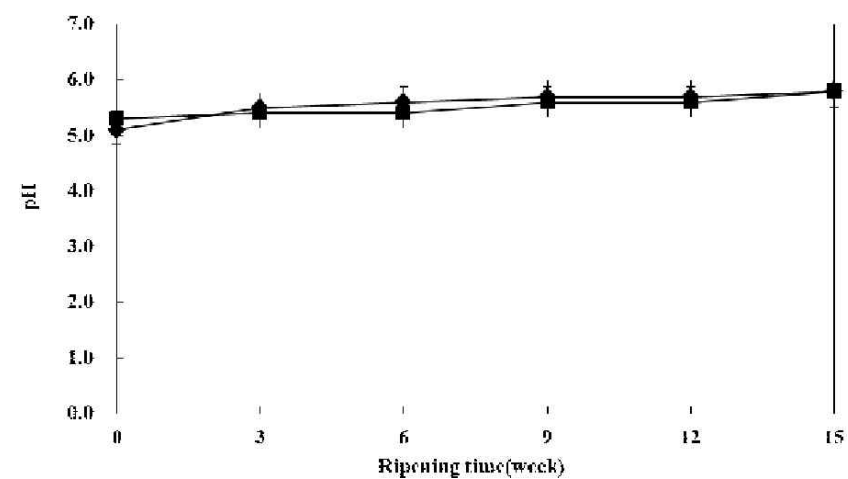

$\checkmark$ : Control cheese,

- Cheese added with fish Surimi $1.0 \%$.

Fig. 2. Changes in $\mathrm{pH}$ during the ripening period of Gouda cheese added with fish Surimi.

\section{NCN, NPN, WSN의 변화}

각 치즈의 숙성기간 중 질소화합물 변화는 Fig. 3-5에서 보는 바 와 같이 치즈 숙성이 진행됨에 따라 치즈 단백질 분해가 일어나 비 단백태 질소화합물 $(\mathrm{NPN}), \mathrm{pH} 4.6$ 가용성 질소화합물 $(\mathrm{NCN})$, 수 용성 질소화합물 $(\mathrm{WSN})$ 등의 함량이 모두 증가하였다. $\mathrm{NPN}$ 의 경 우 숙성개시와 더불어 단백질 함량이 증가하였고 어육 수리미를 첨 가한 첨가 구에서 대조구보다 높은 NPN 증가가 나타났다. 이는 Aston 등(1983)의 보고에서 TCA 가용성 질소화합물인 NPN은

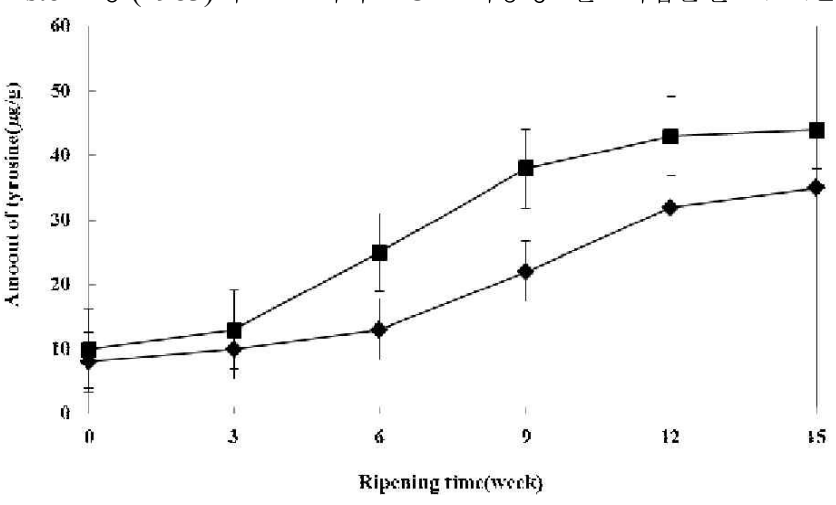

- Cheese added with fish Surimi 1.0\%.

Fig. 3. Changes of Non-protein nitrogen (NPN) during the ripening period of Gouda cheese added with fish Surimi.

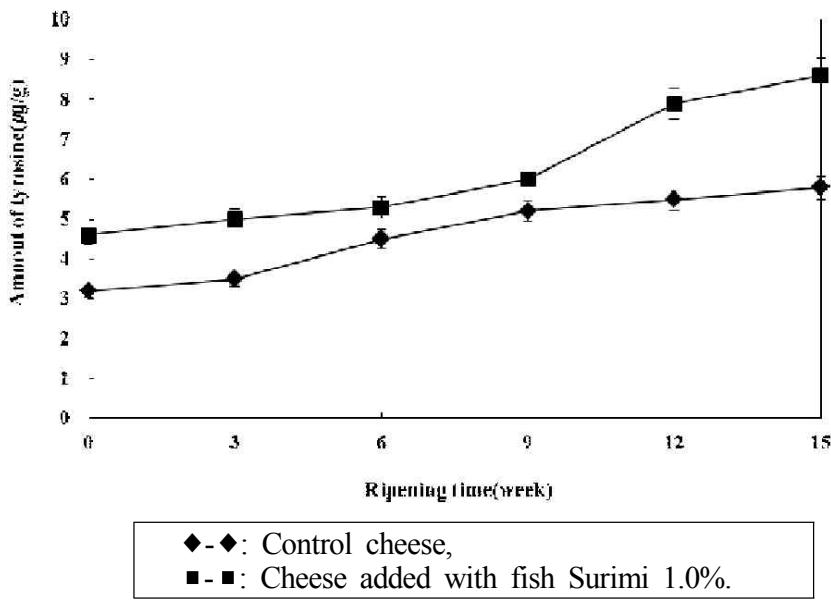

Fig. 4. Changes of Non-casein nitrogen (NCN) during the ripening period of Gouda cheese added with fish Surimi.

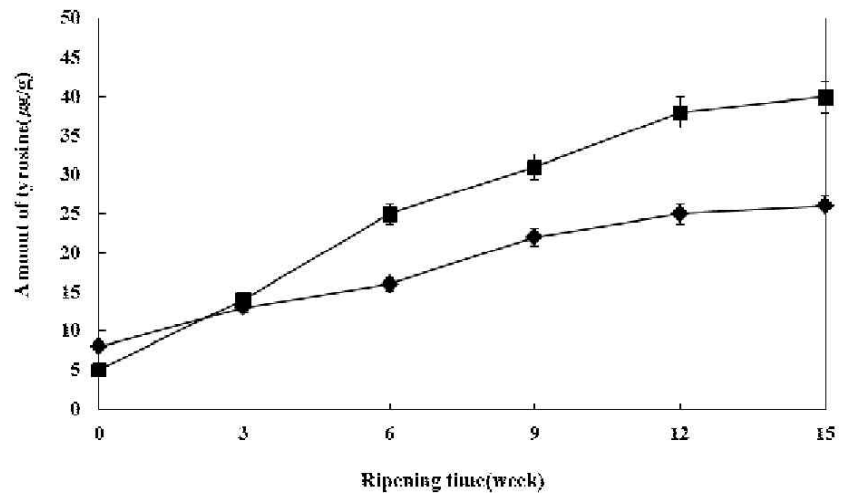

$\diamond-\diamond:$ Control cheese,

- : Cheese added with fish Surimi $1.0 \%$.

Fig. 5. Changes of Water-soluble nitrogen (WSN) during the ripening period of Gouda cheese added with fish Surimi.

치즈가 숙성됨에 따라 치즈단백질이 peptide로 분해되어 숙성이 오 래 진행될수록 증가하는 경향을 나타낸다고 한 것과 일치하는 결과 를 나타내었다.

Rank 등 (1985)도 치즈 casein 중 pH4.6 buffer에 가용성인 성 분은 주로 소형 분자량으로 된 peptide 결합물이며 이러한 질소 화 합물은 대부분이 렌넷 작용에 의해 생성되는 것들이라고 하였고 치 즈 숙성기간이 경과함에 따라 증가한다는 보고를 하여 $\mathrm{NPN}$ 과 $\mathrm{NCN}$ 함량 증가가 치즈 숙성도 판단 지표가 될 수 있음을 제시한 바 있다. 한편, Barlow (1989)는 치즈 단백질의 수용성 질소량 (WSN)이 높을수록 숙성도 측정결과는 높게 나타난다고 보고한 바 있어 본 시험 결과의 신빙성을 뒷받침 해 주었다.

\section{4. 전기영동 변화}

치즈의 숙성 중 각 Casein 단백질의 분해 도는 Fig. 6에 나타내 


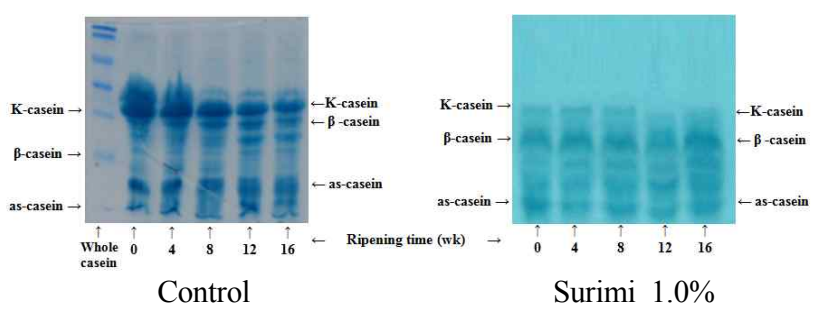

Fig. 6. Proteolytic activity of Gouda cheese added with fish Surimi $1.0 \%$.

었다. 어육 수리미를 첨가한 가우다 치즈에서 숙성기간 중 수용성 질소화합물의 변화는 Fig. 6에서 보는 바와 같이 치즈 숙성이 진행 됨에 따라 각 Casein 단백질 분해가 일어나 질소화합물의 함량이 증가하는 것으로 나타났는데 이러한 결과는 Visser 등 (1977)은 치 즈 숙성 중 $a \mathrm{~s}$-casein은 숙성 1개월 후 분해가능성을 보고하였으 나 수리미 가우다 치즈에서는 그 보다는 지연된 분해를 보여 차이 가 있었고, 치즈의 쓴맛 peptide 출현을 유발하는 $\beta$-casein의 경우 대조 구와 수리미 가우다 치즈에서 큰 분해도 차이가 관찰되지 않 았다. 또한 치즈의 숙성중 전기영동 상을 통해 치즈 단백질 분해도 판단기준이 되는 미세 밴드 출현이 첨가구보다 대조구에서 더 많이 나타났다. 이는 첨가구의 경우 치즈 내 유산균 스타터 유래 단백질 분해효소와 Peptidase의 활력이 치즈에 첨가 된 어육 수리미 유래 단백질에 대해서는 그 분해활력이 미치지 못했던 결과로 보인다. 다만 치즈 숙성 중의 각종 질소화합물의 변화를 통해 검토한 치즈 의 숙성 도는 대조구보다 어육 수리미 첨가구가 더 높은 것으로 나 타나 치즈 제조 시 어육 수리미 첨가가 치즈 숙성 도에 다소 유리 한 영향을 미치는 것으로 사료되었다.

\section{5. 치즈의 일반성분}

어육 수리미를 첨가하여 제조한 가우다 치즈의 일반성분은 Table 1에 나타내었다. 대조구 가우다 치즈의 수분은 $34 \%$, 조회분 과 조단백질, 조지방의 함량은 각각 $3.24 \%, 25.16 \%, 36.8 \%$ 로 수 리미를 첨가한 가우다의 수분은 $35.31 .0 \%$. 조회분이 $3.63 \%$ 로 대

Table 1. Chemical composition of the Gouda cheese added with fish Surimi

\begin{tabular}{|c|c|c|}
\hline \multirow{2}{*}{ Component } & \multicolumn{2}{|c|}{ Treatment } \\
\hline & Control & Fish Surimi $1.0 \%$ \\
\hline Moisture & $\bar{a} 34.95 \pm 0.035^{\mathrm{a}}$ & $\mathrm{b}_{35.31 \pm 0.049^{\mathrm{b}}}$ \\
\hline Crude ash & ${ }^{\mathrm{b}} 3.24 \pm 0.022^{\mathrm{b}}$ & ${ }^{\mathrm{a}} 3.63 \pm 0.012^{\mathrm{a}}$ \\
\hline Crude protein & ${ }^{\mathrm{b}} 25.16 \pm 0.260^{\mathrm{b}}$ & ${ }^{\mathrm{a}} 25.65 \pm 0.093^{\mathrm{a}}$ \\
\hline Crude fat & ${ }^{N S} 36.80 \pm 0.288$ & $36.93 \pm 0.135$ \\
\hline
\end{tabular}

Mean \pm S.D. $(n=36)$. Means with different small character superscripts in each row are significantly different $(\mathrm{p}<0.05)$. Means with different large character superscripts in each column are significantly different $(\mathrm{p}<0.05)$.
조구와 유의적인 차이 $(\mathrm{P}<0.05)$ 를 보이지 않는 것으로 나타났다.

\section{6. 소비자 기호도 검사}

어육 수리미를 첨가하여 제조한 가우다 치즈의 소비자 기호 도는 Table 2에서 보는 바와 같다. 치즈의 기호도 평가 결과 치즈 색을 제외한 향미, 조직도, 전체적인 기호도 부분에서 대조구보다 다소 높은 값을 보였으나 유의적 차이는 없는 것으로 나타났다. 특히 조 직 감에서 대조구는 $3.96 \%$ 를 나타냈지만 첨가 구에서는 $4.19 \%$ 로 나타나 어육 수리미 $1.0 \%$ 첨가 구가 조직성에서 좋은 점수를 나타 냈는데 이러한 점을 반영하기 위하여 1 2개월의 단시간 숙성된 제 품을 개발하는 것도 고려해야 할 것으로 사료되었다.

Table 2. Affective test of the Gouda cheese added with fish Surimi

\begin{tabular}{ccc}
\hline \multirow{2}{*}{ Item } & \multicolumn{2}{c}{ Treatment } \\
\cline { 2 - 3 } & Control & Fish Surimi $1.0 \%$ \\
\hline \hline Color & ${ }^{\mathrm{a}} 5.10 \pm 1.73^{\mathrm{a}}$ & ${ }^{\mathrm{b}} 4.98 \pm 1.96^{\mathrm{b}}$ \\
Flavor & ${ }^{\mathrm{b}} 3.50 \pm 1.85^{\mathrm{a}}$ & ${ }^{\mathrm{a}} 3.78 \pm 2.07^{\mathrm{b}}$ \\
Texture & ${ }^{\mathrm{b}} 3.96 \pm 1.76^{\mathrm{a}}$ & ${ }^{\mathrm{a}} 4.19 \pm 1.99^{\mathrm{b}}$ \\
Overall acceptability & ${ }^{\mathrm{NS}} 3.54 \pm 1.88^{\mathrm{NS}}$ & $3.67 \pm 1.93$ \\
\hline
\end{tabular}

Mean \pm S.D. $(n=36)$. Means with different small character superscripts in each row are significantly different $(p<0.05)$. Means with different large character superscripts in each column are significantly different $(\mathrm{p}<0.05)$

7. 관능검사

어육 수리미를 첨가하여 제조한 가우다 치즈의 aroma of butter, salty, bitterness, astringency, butyric acid를 검사한 관능평가 결 과는 Table 3에서 보는 바와 같다. 그 중 수리미를 첨가한 치즈의 관능검사 결과 수렴 성 (Astringency) 부분에서 낮은 평가를 받았

Table 3. Sensory evaluation of Gouda cheese added with fish Surimi

\begin{tabular}{ccc}
\hline \multirow{2}{*}{ Item } & \multicolumn{2}{c}{ Treatment } \\
\cline { 2 - 3 } & Control & Fish Surimi $1.0 \%$ \\
\hline \hline Aroma of Butter & ${ }^{\mathrm{NS}} 5.63 \pm 2.02^{\mathrm{NS}}$ & $5.67 \pm 2.15$ \\
Salty & ${ }^{\mathrm{b}} 5.85 \pm 2.19^{\mathrm{b}}$ & ${ }^{\mathrm{a}} 6.00 \pm 1.79^{\mathrm{a}}$ \\
Bitterness & ${ }^{\mathrm{a}} 5.48 \pm 1.27^{\mathrm{a}}$ & ${ }^{\mathrm{b}} 5.35 \pm 2.11^{\mathrm{b}}$ \\
Astringency & ${ }^{\mathrm{a}} 6.42 \pm 1.86^{\mathrm{a}}$ & ${ }^{\mathrm{b}} 5.31 \pm 2.08^{\mathrm{b}}$ \\
Butyric acid & ${ }^{\mathrm{b}} 6.42 \pm 2.14^{\mathrm{b}}$ & ${ }^{\mathrm{a}} 6.73 \pm 2.08^{\mathrm{a}}$ \\
\hline
\end{tabular}

Mean \pm S.D. $(n=36)$. Means with different small character superscripts in each row are significantly different $(p<0.05)$. Means with different large character superscripts in each column are significantly different $(\mathrm{p}<0.05)$. 
다. 쓴맛은 대조구가 5.48, 어육 수리미 첨가구가 6.00 으로 대조 구에 비해 어육 수리미 첨가 가우다 치즈가 다소 불리한 평가를 받 았다. 이는 우려할만한 수준은 아니지만 어육 수리미 첨가 치즈에 서 보이는 약간의 쓴맛 출현을 바로잡기 위하여 시제품 제조 시 추 가적인 보완 검토가 요구되었다.

\section{요 약}

본 연구에서는 어육 수리미를 자연 치즈에 접목하여 새로운 치즈 개발에 목표를 두고 반 경질 숙성 치즈 중에서 비교적 온화한 향미 를 가진 가우다 치즈(Gouda Cheese)에 예비실험을 통하여 얻어진 최적 첨가량인 $1.0 \%$ 어육 수리미를 첨가, 제조한 가우다 치즈의 전반적인 품질변화와 소비자 기호 도를 검토하였다.

본 연구의 치즈 단백질 분해도는 숙성기간이 경과함에 따라 어육 수리미 첨가구가 대조구에 비해 유의적으로 다소 높게 나타났다. 일반성분과 소비자 기호도 및 관능평가 부분에서는 대조구와 첨가 구에서 유의적인 차이가 나타나지 않았다. 이상의 결과를 종합하면 어육 수리미의 첨가가 치즈 제조상의 특성이나 품질변화에는 큰 영 향을 미치지 않고 치즈의 숙성과정에서 단백질 분해를 촉진하면서 치즈의 맛을 개선하였으므로 어육 수리미 이용, 신규 기능성 치즈 개발이 가능함을 확인하였다.

(주제어: 가우다 치즈, 어육 수리미, 치즈 숙성, 소비자 기호도 검사)

\section{감사의 글}

본 연구는 중소기업청의 2008년도 중소기업 기술혁신개발사업 과제의 연구비 지원을 받아 수행한 연구결과의 일부로써 이에 감사 드립니다.

\section{인 용 문 헌}

Aston, J. W., Durward, I. G. and Dulley. 1983. Proteolysis and flavor development in Cheddar cheese. Aust. J. Dairy Technol. 38:55-59.

AOAC. 1990. Official Methods of Analysis, $13^{\text {th }}$ ed. Association of Official Analytical Chemists. Washington D.C., U.S.A., pp.155139.

Barlow, I., Lloyd, G. T., Ramshaw, Z. H., Miller,A. J. and McCabe, G. P. 1989. Correlations and changes in flavor and chemical parameters of Cheddar cheese during maturation. Aust. J. Dairy Technol. 44, 7-18.

Bütikofer, M., Rüegg, M. and Ardö, Y. 1993. Determination of nitrogen fractions in cheese: evaluation of a collaborative study. Lebensm. Wiss. Technol. 26:271-275.

Choi, Y. J., Lee, H. S. and Cho, Y. J. 1999. Optimization of ingredients formulation in low grades surimi for improvement of gel strength. J. Korean Fish. Soc. 32, 556-562.

Choi, Y. J., Park, J. D., Kim, J. S., Cho, Y. J. and Park, J. W. 2002. Rheological properties of heat-induced gels of surimi from acid and alkali process. J. Korean fish. Soc. 35(4):309-314.

Creamer, L. K., Zoerb, N. F. and Richardson, T. 1982. Surface hydrophobicity of as1- I, $a$ s1-casein A and B its implications in cheese structure. J. Dairy Sci. 65: 902-906.

Davis, F. L. and Law, B. A. 1984. Microorganisms and their enzymes in the maturation of cheese. Progr. In Ind. Microbiol. 19:245-283.

Ellen, E. O. 2006. The Vermont cheese book. The countryman press. Woodstock, Vermont. p. 10.

Hill, A. R. 2007. Cheese Science and Processing Technology (translated by Inhyu Bae, Jonggun Ahn). Yuhan Publ. Co., Seoul. pp. 206-207.

Hull, M. E. 1947. Studies on Milk protein Colorimetric Determination of the partial Hydrolysis of the proteins in Milk. J. Dairy. Sci. 30:881-884.

Jin, S. K., Kim, I. S., Yang, H. S., Choi, Y. J. and Kim, B. G. 2007. Quality Characteristics of Surimi Manufactured by Alaska Pollack, Barren Hen Breast Meat and Mechanically Deboned Chicken Meat. J. Anim. Sci. \& Technol. 49(3):395-404.

Jin, S. K., Kim, I. S., Nam, Y. W., Park, S. C., Choi, S. Y., Yang, H. S. and Choi, Y. J. 2008. Comparison of Textural Properties of Crab-flavored Sausage with Different Proportions of Chicken Meat. Korean J. Food Sci. Ani. Resour. 28(4):395-400.

Lanier, T. C. 1986. Functional properties of Surimi. Food Tech Reviews. 40:107-114.

Laemmi, U. K. 1970. Cleavage of structural proteins during the assembly of the head of bacteriophage T4. Nature. 277:680-685.

Morris, C. J. 1979. Separation methods in biochemistry, Pitmat Publishing, 2nd., pp. 415-470.

Park, J. W. and Morrissey, M. T. 2000. Manufacturing of surimi from light muscle fish. In Surimi and Surimi Seafood, J. W. Park, ed. Marcel Dekker, New York, pp. 23-58.

Park, D. J., Jung, C. H., Kim, J. S., Cho, D. M. and Choi, Y. J. 2003. Surimi Processing Using Acid and Alkali Solubilization of Fish Muscle Protein. J. Korean Soc. Food Sci. Nutr. 32(3):400405.

Rank, T. C., Grappin, R. and Olsen, N. 1985. Secondary proteolysis of cheese during ripening: A review. J. Dairy Sci. 68:801-805.

SAS. 1999. SAS/STAT Software for PC. User's guide, SAS Institute Inc., Cary NC, U.S.A.

Visser, F. M. W. and de groot-Mastert, A. E. A. 1977. Contribution of enzymes from rennet, starter bacteria milk to proteolysis and flavor development in Gouda cheese. 4. Protein breakdown; a gel electrophoretical study. Neth. Milk Dairy J. 31:210-239.

(Received Jun. 17, 2011; Revised Feb. 17, 2012; Accepted Feb. 21, 2012) 